\title{
The Intersection of Law and Ethics - at 600 Grant Street, Pittsburgh, PA: Is it Ethical to Assert a Legal Technicality to Avoid Liability for a Debt Created by Fraud?
}

\begin{abstract}
A considerable literature exists regarding the moral obligation to keep one's promises. Several authors have focused on the exceptional circumstances which may or should excuse this moral duty. Less frequently discussed is the question of how this general moral obligation and its possible exceptions play out in the context of negotiable written promises to pay money, i.e., so-called "commercial paper."

This paper focuses on the application of the legal rules governing commercial paper, and on the ethical implications involved in the application of those rules. More specifically, it asks whether the assertion of the technical doctrine known as "holder in due course," and the denial of that status in some cases, promotes ethical behavior in the marketplace. By examining the circumstances of one case, involving a substantial investment and a large bank, I hope to shed some light on how the legal and ethical rules do in fact "intersect."
\end{abstract}

\section{Introduction}

Modern global capitalism requires - almost by definition - the availability of large amounts of mobile capital. The biggest projects may need massive funding - tens of millions, or even hundreds of millions of dollars. The huge multinational corporations may be capable of generating much of their funding internally, by reinvesting profits, but even they sometimes need additional financial infusions from "the outside." For would-be entrepreneurs, and smaller existing firms, exploitation of their great new ideas will typically require "selling" the new idea to persons who have money to invest. These individuals or organizations may be asked to take an equity stake in the new venture, or simply to lend money. Our examples here concern equity investors.

The promoter of the new project explains it to the prospective investor, who is persuaded to make the investment. If the project succeeds, profits are made and distributed - and everyone is happy. If the project fails, and bankruptcy ensues, the investor has lost the amount advanced and is likely to be quite $u n$-happy (although there may be some beneficial, if unintended, tax consequences). Economic history provides many examples of spectacular successes - and spectacular failures. ${ }^{1}$

\section{The defrauded investor}

Our problem here is more complicated, for several reasons. First, our investor did not advance cash money to the promoter, but rather promised to pay the amount of the agreed investment, at some future time, in the form of a negotiable promissory note. Second, the investor was defrauded by the promoter, who knowingly misrepresented significant facts about the nature and circumstances of the project. And finally, the dispute is no longer between the promoter/crook and the investor/victim, because the promissory 
note has been sold by the promoter to a bank or other third party, who is now trying to enforce it against the defrauded investor.

It is this third-party lawsuit against the defrauded investor that raises the legal and ethical questions we want to examine.

\section{Negotiable instruments}

Commercial paper was created several centuries ago by the merchants of medieval Europe. ${ }^{2}$ With brigands in the woods, and thieves in the towns, carrying large sums of cash was extremely hazardous, to say the least. (It's safe to say that things are only marginally better today, in that regard.) What the merchant community needed was a payment mechanism that would be generally accepted in lieu of cash. Their solution was commercial paper - written promises to pay cash, or orders to another person to pay cash. Based on the rules and understandings developed, sellers of goods and services could receive these "scraps of paper" ${ }^{3}$ from their buyers, and then sell them to third parties for cash. The third parties were assured that if they bought the instruments in good faith, they would collect from the buyer/debtors in most cases. This assurance was given through application of the "holder in due course" doctrine.

In simplest terms, the holder in due course doctrine says that the good faith transferee of a negotiable instrument (the HDC) can enforce it as written, despite the existence of certain problems in the underlying transaction. For instance, the seller's non-delivery of the promised goods or nonperformance of the promised services will not prevent the HDC of a negotiable instrument from collecting against the disappointed buyer. Likewise, the seller's misrepresentation of the goods or services does not prevent the HDC from receiving the full amount of the instrument. Buyers who have executed such instruments are required to pay for the proverbial "dead horse" - and then to seek whatever recourse they can from their seller.

In the United States, commercial paper law was codified first in the Uniform Negotiable Instruments Law (N.I.L.), and then as Article 3 of the Uniform Commercial Code (U.C.C.) The $\mathrm{UCC}$ is currently in force in all 50 states.

\section{Northwestern v. Maggio}

The application of the HDC rules in a defrauded investor case is illustrated by Northwestern National Insurance Co. v. Maggio. ${ }^{4}$ In 1981, Maggio invested in a limited partnership organized by a former astronaut to develop an optoelectronic scanner to provide security at airports, oil fields, and similar installations. Maggio signed a $\$ 55,000$ noninterest-bearing negotiable note representing his investment. The note, due in 1990, was sold first to a venture-capital company, and then resold to Goldman Sachs, an investment firm. Goldman Sachs, in turn, sold it at a 50 percent discount to Northwestern. When the note came due in October, 1990, Maggio refused to pay Northwestern, claiming that he had been defrauded by the promoters of the limited partnership.

The specific issue raised in the case was whether Northwestern could qualify as an HDC, since it had paid only half of the note's face value, and had bought it as part of a large group of notes. Maggio claimed that the large discount and the "bulk" purchase disqualified Northwestern as an HDC, and that he could thus assert his fraud defense to avoid liability. ${ }^{5}$ Both the U.S. District Court and the U.S. Seventh Circuit Court of Appeals ruled in favor of Northwestern. Maggio had to pay for his "dead horse."

\section{Manufacturers Hanover Trust v. Robinson}

The specific ethical question we are asking is raised by the facts in Manufacturers Hanover Trust v. Robinson. ${ }^{6}$ Robinson and the other investors signed a total of forty promissory notes, each of which was for $\$ 2$ million, representing their investments in a limited partnership to develop the office building at 600 Grant Street, Pittsburgh, PA. The promoters failed to disclose the presence of asbestos in the building (which would make it much more expensive to 
renovate), and seriously misrepresented the amount of already available vacant office space in the city (which would make it much more difficult to rent space in a renovated 600 Grant building). The promoters of the 600 Grant Street Associates Limited Partnership (GSALP) sold Robinson's note directly to Manufacturers, and sold the other 39 notes to two other banks. Those two banks, Marine Midland and Security Pacific, later re-sold the other 39 notes to Manufacturers. Marine indorsed 37 notes as follows:

"PAY TO THE ORDER OF WITHOUT RECOURSE MARINE MIDLAND BANK, N.A. BY (signature of bank officer)."

Security Pacific used similar language to transfer the two notes it sold to Manufacturers.

At this point, under commercial paper rules, Manufacturers was an HDC of all 40 notes, and thus entitled to collect the entire $\$ 80,000,000$ from the defrauded investors. That would have been the result, but for the intervention of certain Manufacturers' personnel.

When 600 GSALP defaulted in making promised payments to its investors, bank officers at Manufacturers became concerned about the collectibility of their $\$ 80$ million worth of promissory notes. They went to the vault and removed the notes. For some "inexplicable" reason, using a rubber stamp, the officers then stamped "600 GRANT STREET ASSOCIATES LIMITED PARTNERSHIP" in the blank space on the original indorsements of the 39 notes from Marine Midland and Security Pacific. With that indorsement, the notes again belonged to 600 GSALP - the crooks! Then, acting as agents for 600 GSALP (they had been so authorized), the Manufacturers officers indorsed the 39 notes back to Manufacturers: "600 Grant Street Associates Limited Partnership without recourse. By: Manufacturers Hanover Trust Company as Agent, Attorney-in-fact for 600 Grant Street Associates Limited Partnership. By: (signature of officer) Vice President." Now the 39 notes were again owned by Manufacturers. (Robinson's note did not go through this process, since it had been purchased directly from 600 GSALP by Manufacturers.)

At the point in time when Manufacturers thus "reacquired" the 39 notes from 600 GSALP, it was aware of possible irregularities in the original transaction. Its officers had gone to "inventory" the notes precisely because they were concerned about the possibility of litigation. As a reacquirer with notice of irregularities concerning the notes, they could not qualify at that point as an HDC. $^{8}$ (There could also be a question as to whether they $r$-acquired the 39 notes "for value."') ${ }^{9}$

Manufacturers had an alternate argument, however. The law of commercial paper provides a so-called "Shelter Rule." A transferee of the instrument who does not personally qualify as an HDC can still claim all the rights of an HDC, if the transferor was an HDC. Thus, a holder from an HDC can enforce the instrument as written, free of most of the debtor's claimed defenses against liability. Manufacturers claimed that both of the other banks had been HDCs - and so had it, for that matter, before the vice president got loose in the vault with his rubber stamp. With an HDC (or two) in its chain of title, Manufacturers argued, it should be able to collect the other 39 notes, as well as Robinson's note.

The difficulty with this argument is that Manufacturers' immediate transferee was not an HDC, but rather 600 GSALP - the crooks. The legal question the court had to answer to decide the case was the scope of the Shelter Rule. Does the Rule apply only in favor of a holder from a holder in due course, i.e., only when there is a transfer from an HDC to a non-HDC, so that only the immediate transferee is protected? Or does the Rule protect any and all holders through a holder in due course, i.e., all later owners of the instrument, even though they did not acquire the instrument directly from the prior HDC owner? Justice Lehner acknowledged that there had been some ambiguity on this point under the old N.I.L., but he thought that the applicable UCC section clearly pointed to the more limited interpretation. ${ }^{11}$ When it reacquired the 39 notes from 600 GSALP, then, Manufacturers got all the rights of 600 GSALP. If the alleged fraudulent misrepresentations of the promoters can be proved, Manufacturers will not be able to collect the $\$ 78$ million represented by the other 39 notes. Poor Mr. Robinson, however, 
will still have to pay for his dead horse, since Manufacturers is an HDC of his $\$ 2,000,000$ note.

\section{The ethical question}

A considerable literature exists regarding the moral obligation to keep one's promises. ${ }^{12}$ Most commentators seem to accept "promise-keeping" as a moral/ethical duty; indeed, one widely-distributed pamphlet on business ethics lists "Honor Your Promises and Commitments" as number one on its list of " 50 Ways to 'Walk the Talk'." There are, however, several well-recognized exceptions to this duty to perform as promised. One whose promise was coerced by force or threat of force should be able to disaffirm the promise when the threat is removed..$^{14}$ Likewise, persons lacking the legal capacity to form agreements - children, the mentally disabled, et al. should not be held responsible for performance of their promises. ${ }^{15}$ Most relevant for our immediate problem, persons whose promises were induced by the other party's fraud should not be bound to fulfill those promises. ${ }^{16}$ Such is the legal rule. ${ }^{17}$ Indeed, the Law generally gives the defrauded party the option of having the fraudulently-induced performance undone, if it has already been given to the liar before the fraud is discovered. ${ }^{18}$ It would seem logical - and fair that the moral/ethical rule should parallel the legal one on this point. Any other position would require the victim to acquiesce in the wrongdoing, which hardly seems an ethically correct injunction.

To apply the foregoing analysis to the Robinson situation, it seems clear that the defrauded investors would be ethically/morally justified in refusing to pay the promoters - the crooks at 600 GSALP - if the promoters themselves had sued to collect the $\$ 80$ million. Surely a wrongdoer should have no ethical standing when s/he asserts a claim based on his or her own wrongful conduct. ${ }^{19}$ Surely no ethical system worthy of the label can mandate performance of promises induced by the promisee's wrongful (indeed, criminal) conduct. Posed as an issue between the promisor/victim and the promisee/criminal, the ethical choice seems clear: it is ethical to refuse to pay the criminal.

But again, that is not the exact situation presented in Robinson. The party to whom the promises were originally made - the fraudulent promoters - are not themselves trying to enforce the promises. As indicated above, the promoters sold the promissory notes in question to three banks. Manufacturers Bank, which had bought only one note from 600 GSALP, subsequently bought the other 39 notes from the other two banks and is now suing to enforce all 40 of the notes. Its claim for collecting the money represented by the 40 notes is based on its special status under the law as a "Holder in Due Course." To avoid having to pay, the makers of the other 39 notes (i.e., those that were resold to Manufacturers by the other two banks) are asserting a legal "technicality." Under the current legal rules, Manufacturers can not qualify for HDC status.

Thus we come to the specific problem raised by the Robinson case: Is it ethical to assert a legal technicality to avoid liability on one's contract, where that liability is based on a fraudulent transaction? Phrased more blatantly, in terms of the facts of Robinson - is it ethical to take advantage of the incompetence/stupidity of a bank's vice president, so as to avoid liability to the bank? Posed this way, the question does seem to point towards a "no" answer; no, it's not ethical. "Taking advantage" of someone's innocent (albeit stupid) mistake would not seem to be "praiseworthy" conduct. However, a closer look discloses that the problem is not quite that simple.

In the first place, the bank is itself trying to use a legal technicality - the HDC rule - to "take advantage" of the buyer by enforcing a fraudulent contract. But for the concept of negotiability and the attendant HDC rule, the defrauded buyer could assert the seller's fraud to prevent the transferee of the account receivable from collecting. It is only because of the technical HDC rules that a defrauded buyer is prevented from doing so. It is in fact generally true that a transferee of property receives only as much interest in that property as the transferor had. ${ }^{20}$ One who buys goods from a thief has to return them to the rightful owner, even though 
the buyer was acting in good faith at the time of purchase; a person with no title can pass no title, even to a good faith purchaser. ${ }^{21}$ However, the same section of the UCC also says that a person with voidable title to goods has the power to pass a valid title to a good faith purchaser. ${ }^{22}$ (The transferee has a voidable title where there was a voluntary transfer, but the transferor was defrauded, or lacked mental capacity to make a binding contract.) For real estate transfers, which are not covered by the UCC, the general rule prevails. ${ }^{23}$ Thus the law goes both ways on this type of problem, and "the devil is in the details."

Second, the collectibility of the 39 notes depends on the bank's status as an HDC. If it is not an HDC, the 39 investors who signed the notes can use the promoters' fraud to avoid liability. ${ }^{24}$ The legal technicality which prevents the debtor from asserting defenses is thus dependent on a further technicality - the status of the holder as an HDC. ("He who lives by technicalities shall perish by technicalities.")

Third, both parties to the lawsuit failed, in a sense, to do adequate "due diligence" on the underlying project - the investors initially, and the bank when it purchased the notes. There is thus more than enough "fault" to go around. Arguably, the bank is even more at fault, since it was its own stupidity that denied it the necessary status as HDC, after it had initially achieved that status. Where one of two "innocent" parties must sustain a loss, the law generally places the loss on the party who was better able to avoid its occurrence. ${ }^{25}$ In our case, that appears to be the bank.

Fourth, while these are undoubtedly wealthy, sophisticated investors, it is the bank and its officers who are the "pros from Dover." Finance is the bank's business! They must know the rules of the game they are playing! They are responsible for knowing them! Their failure to know them and to use them is gross incompetence of the worst kind! Indeed, the officers involved should be summarily dismissed, or at the very least demoted to positions where they have no access to funds or documents.

Fifth, if there are policy reasons for protecting HDCs, so as to ensure the availability of capital, that protection should be carefully circumscribed (as it in fact is). Recognizing the injustice of the HDC rule in consumer transactions, the Federal Trade Commission adopted Regulation 433, which essentially abolishes the HDC rule in "consumer transactions." 26 Banks and finance companies who are buying consumer accounts are thus required to do "due diligence" investigations of the goods and services sellers from whom the financing agencies are buying the consumer accounts. As defined, however, Regulation 433 does not apply to investment contracts, or to sales of goods with a purchase price of more than $\$ 25,000$. Perhaps the HDC rule does still make sense for the financing of commercial purchases of goods or services. But it's just possible that the rule may need further modification for investment contracts.

\section{Ethical standards}

How do various ethical standards and "tests" apply to our problem? ${ }^{27}$ At minimum, ethical behavior requires compliance with applicable legal rules and requirements. This the investors are doing, by insisting that the full and exact legal requirements of the HDC rule be applied to their situation.

What of the Aristotelian system of ethics? ${ }^{28}$ Certainly, keeping one's promises was a large part of what made a person worthy of honor. But what about promises that were extorted by fraud? Would the person of honor also be required to keep those as well? Perhaps one could argue that the person of honor would take the bitter medicine, perform as promised in favor of an "innocent" third party, and then seek recourse against the wrongdoer. But one could also argue that a person seeking to enforce a promise based on fraud (Manufacturers) was itself without "honor," and thus itself deserving of condemnation.

Biblical injunctions are likewise inconclusive. ${ }^{29}$ Bearing false witness against one's neighbor is condemned in the Ninth Commandment, but it does not condemn "lying" in generic terms. Committing fraud would surely seem to violate the mandate to "do unto others as you would have them do unto you." That application, 
however, only condemns the crooked seller; it provides no guidance to the victim of the fraud as to the necessity of honoring the fraudulently induced promise.

Nor does the Kantian imperative - "act always in such a way that you could compel your behavior to be universalized" - seem to shed much light on our problem. "In fact, our investors' behavior has been "universalized," by the applicable section of the Uniform Commercial Code! We can of course still debate whether society has chosen to universalize the correct rule on this point, but the fact remains that we have in fact already adopted a "universal rule" covering this situation.

What about the "greatest good for the greatest number" formulation of the Utilitarians? The mathematics of our problem are anything but clear. Noting that there are always more debtors than creditors will not advance the analysis very far, since application of the HDC rules may have both good and bad effects on both debtors and creditors. Denial of HDC status in certain situations may have the long-term effect of increasing the cost of credit, or even its denial altogether, to the ultimate detriment of debtors. On the other hand, if the rules force third-party financers to perform better "due diligence" investigations, defaults may decrease, to the ultimate benefit of all parties. Thus, as is true in many such situations in the private sector, it's not easy to calculate just what the "greatest good" really is.

There might also be differing views on how the "Public/Family Knowledge" Test would apply to our problem. As one of the investors, would/should you be ashamed to have it widely known that you had refused to pay your $\$ 2$ million note because you had been defrauded? One suspects that most people would be more ashamed to have it known that they had been defrauded, than that they had subsequently (and successfully) refused to pay their notes. Being the victim of a fraud implies a certain degree of stupidity, or at least gullibility. Refusing to pay the fraudulently-induced obligation indicates a willingness to stand up for one's rights. One could certainly imagine that many of these investors would be enthusiastically telling friends and associates of this successful thwarting of the attempted fraudulent scheme. One also imagines that poor Mr. Robinson would not be broadcasting his "honorable" $\$ 2$ million payment for a dead horse. It's also a bit difficult to believe that an investor who paid the $\$ 2$ million even though not legally required to do so would earn many public encomiums; the public reaction might rather be: "what a dumb thing to do!"

At best, then, these various ethical tests and standards seem to provide inconclusive guidance in answering the original question posed by the Manufacturers case. If anything, they seem to point to a "yes" answer: "yes, it is ethical to use one legal technicality to cancel another legal technicality." It is "honorable" to stand up for one's rights, to try to frustrate the fraudulent scheme, to refuse to play the role of a passive victim. If we can agree that it is honorable to resist evil, and fraud is evil, then it must be resisted. If the basic HDC rule has the unintended effect of promoting fraud, then the limitations and qualifications surrounding the HDC rule must be used whenever possible to keep fraud confined within as small a territory as possible.

To the 39 investors, congratulations! To Mr. Robinson, condolences. To Manufacturers (and especially, the vice president with the rubber stamp), condemnation - and a recommendation: learn your business!

\section{Notes}

1 See, e.g., Robert L. Heilbroner, The Worldly Philosophers, New York: Simon and Schuster, 1980, at p. 35 (describing the "bare-faced fraud" of John Law and his Mississippi Company in 18th century France). 2 George D. Cameron III and Philip J. Scaletta, Jr., Business Law: Environment, Transactions, and Regulation, sixth edition, Cincinnati, OH: Dame/Thomson Learning, 2000, p. 457; Edward L. Rubin, "Learning from Lord Mansfield: Toward a transferability Law for Modern Commercial Practice," 31 Idaho L. Rev. 775 (1995), at 775: "Negotiability is one of the great legal concepts of the Western world, one that has been with us longer than democracy or human rights."

3 The phrase is from the movie Ivanhoe. Ivanhoe and his father Cedric are attempting to gather the ransom demanded for King Richard. They have assembled a tableful of coins, jewels, jewelry and miscellaneous 
valuables. The merchant Isaac of York comes to make good his pledge on behalf of his people. He adds several documents to the pile. Cedric asks whether these "scraps of paper" have any worth. Isaac explains that "they call on our debtors to pay what they owe." 4976 F.2d 320 (7 Cir. 1992).

5 See UCC, Sections 3-302(2)(v) and 3-306; Stewart v. Thornton, 568 P.2d 414 (AZ 1977).

6597 N.Y.S.2d 986 (Sup.Ct. 1993).

7 The adjective is Justice Lehner's characterization of the bizarre behavior of the bank's vice president.

8 See, UCC, Sections 3-302(2)(v), 3-306, and 3-203(b).

9 See, UCC, Sections 3-302(2) and 3-303.

10 See, UCC, Section 3-203(b).

11597 N.Y.S.2d 986, at 992.

12 See, e.g. Frank Menetrez, "Consequentialism, Promissory Obligation, and the Theory of Efficient Breach," 47 UCLA L. Rev. 859 (February 2000); C. Scott Pryor, "Mission Possible: A Paradigm for Analysis of Contractual Impossibility at Regent University," 74 St. John's L. Rev. 691 (Summer 2000); Stephen A. Smith, "Justifying the Law of Unjust Enrichment," 79 Tex. L. Rev. 2177 (June 2001).

13 Eric Harvey and Scott Airitam, "Ethics 4 Everyone," Dallas, TX: Performance Systems Corporation 2002, at 31.

14 See, e.g., David W. Lutz, "Book Review: The Philosophical Origins of Modern Contract Doctrine," 41 Am. J. Juris. (1996); Henry Mather, "Searching for the Moral Foundations of Contract Law," 47 Am. J. Juris. 71 (2002); Hamish Stewart, "A Formal Approach to Contractual Duress," 47 U. Toronto L.J. 175 (Spring 1997).

15 See, e.g., Larry A. DiMatteo. "Equity's Modification of Contract: An Analysis of the Twentieth Century's Equitable Reformation of Contract Law," 33 New Eng. L. Rev. 265 (Winter 1999).

16 See, e.g., Lutz, supra note 14; Mather, supra note 14; Emily L. Sherwin, "Law and Equity in Contract Enforcement," 50 MD. L. Rev. 253 (Winter 1991); Emily L. Sherwin, "Nonmaterial Misrepresentation: Damages, Rescission, and the Possibility of Effficient Fraud," 36 Loyola L.A. L. Rev. 1017 (Winter 2003); Alan Strudler, "Incommensurable Goods, Rightful Lies, and the Wrongness of Fraud," 146 U. Pa. L. Rev. 1529 (June 1998). Duress, incapacity, and fraud are of course not the only bases for invalidating contracts. See, e.g., DiMatteo, supra note 15 discussing Impossibility, Mistake, Frustration, and Impracticability.

17 See, e.g., Johnson v. Honeywell Information Systems, Inc., 955 F.2d 409 (6 Cir. 1992) - plaintiff has no claim for breach of contract where she lied about her qualifications.

18 See, e.g., Janinda v. Lanning, 390 P.2d 826 (Idaho 1964).

19 Thus, Honeywell (footnote 17) was - presumably - not acting "unethically" when they justified their firing of Ms. Johnson on the basis of her intentional false statements about her qualifications.

20 See, e.g., UCC, Section 2-403(1).

21 See, e.g., Kunstsammlungen zu Weimar v. Elicofon, 678 F.2d 1150 (2 Cir. 1982).

22 UCC, Section 2-403(2).

23 See, e.g., Brown as Guardian of Mary Hall v. Financial Enterprises Corp., 188 Bkr. 476 (D. MA 1988).

24 UCC, Section 3-305.

25 See, e.g., the "entrusting to a merchant" rule in UCC, Section 2-403(2) \& (3); cf., the "last clear chance" doctrine in tort law, which places liability for the accident on the party who had the "last chance" to avoid it. Cameron and Scaletta, supra note 2, at 141-142.

26 Code of Federal Regulations, 16 C.F.R. 433.

27 See, e.g., George D. Cameron III, The Legal and Regulatory Enviornment, second edition, Cincinnati, OH: Dame/Thomson Learning, 2000, pp. 1-6 to 1-8. 28 For statements referencing Aristotle's impact on legal rules, see, e.g., Curtis Bridgeman, "Corrective Jusitce in Contract Law: Is There a Case for Punitive Damages?," 56 Vand L. Rev. 237 (January 2003); James Gordley, "Enforcing Promises," 83 Calif. L.R. 547 (March 1995); C.M.A. McCauliff, "A Historical Approach to the Contractual Ties that Bind Parties Together," 71 Fordham L. Rev. 841 (December 2002), at 860-861, and also 842: "Prosaic and serviceable, contracts remain at the center of our personal, professional, and business arrangements"; Smith, supra note 12 .

29 See, e.g., Pryor, supra note 12 (the "biblical foundations of law," at 692).

30 For statements referencing Kant's contribution of contract law, see, e.g., Sherwin, "Nonmaterial Misrepresentation," supra note 16, at 1026 fn. 2; Strudler, supra note 16, at 1543 and accompanying footnote 26.

University of Michigan, School of Business Administration, 7211 Business School, MI 48109-1234, Ann Arbor, U.S.A. E-mail:gcameron@umich.edu 
